\title{
Skin Carcinoma TNM Finding v7
}

National Cancer Institute

\section{Source}

National Cancer Institute. Skin Carcinoma TNM Finding v7. NCI Thesaurus. Code C88471.

A finding about one or more characteristics of skin carcinoma, following the rules of the TNM AJCC v7 classification system. It applies to skin squamous cell carcinoma, Merkel cell carcinoma, and other nonmelanoma skin carcinomas. (from AJCC 7th Ed.) 